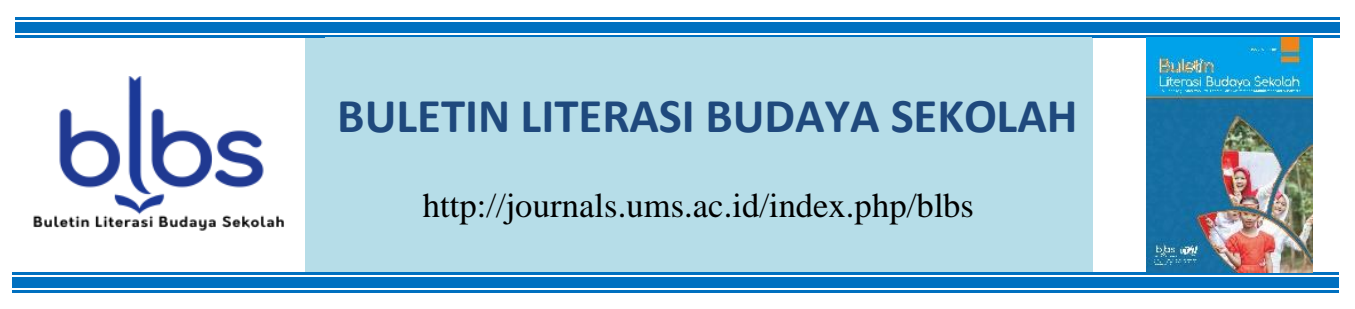

\title{
KONDISI EFEKTIF PESERTA DIDIK DALAM PROSES PEMBELAJARAN DI SMK MUHAMMADIYAH 4 SURAKARTA
}

\author{
Abidah Rohmatillah ${ }^{1}$, Aldila Septiani ${ }^{2}$, Efi Maysaroh ${ }^{3}$, Efri Roziaty ${ }^{4}$, Indah Purnamasari ${ }^{5}$, \\ Meilinia Nurul Alfianti ${ }^{6}$ \\ 1,2,3,4,5,6 Universitas Muhammadiyah Surakarta \\ Jl. Ahmad Yani Tromol Pos I, Surakarta, Indonesia \\ Email \& Phone: abidahrohmatill@gmail.com
}

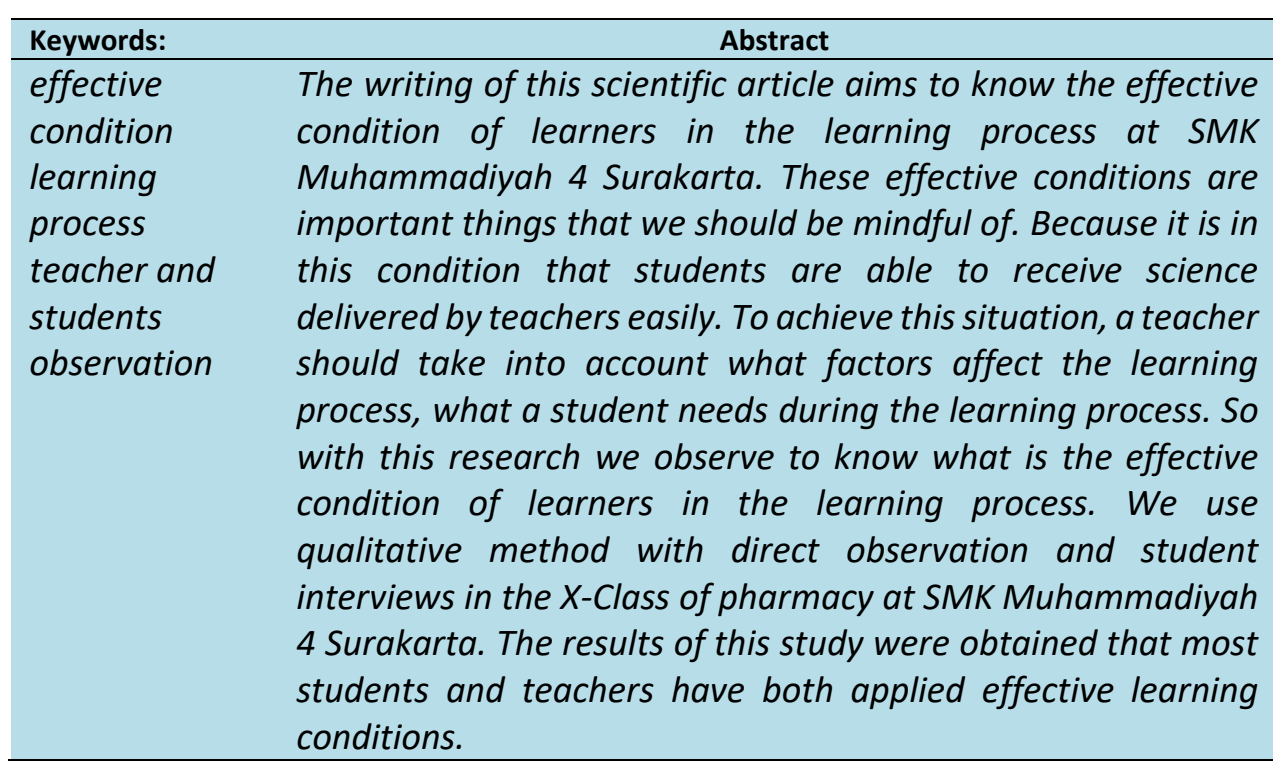

\section{PENDAHULUAN}

Sekolah merupakan salah satu lembaga pendidikan dimana terdapat beberapa komponen didalamnya yang menjalankan suatu kegiatan yang telah dibuat sesuai apa yang telah disepakati bersama sejak lembaga pendidikan itu berdiri. Sekolah mempunyai peran dalam mengembangkan potensi-potensi peserta didik agar mampu menjalankan tugas-tugas dalam kehidupan, baik secara individu maupun sosial. Dalam menjalankan perannya sebagai lembaga pendidikan, sekolah memerlukan tenaga ahli dan profesional untuk menjalankan kegiatan belajar mengajar yaitu guru.

Guru harus memiliki 4 kompetensi meliputi kompetensi pedagogik, kompetensi kepribadian, kompetensi professional, kompetensi sosial. Guru seyogyanya memeiliki perilaku dan kemampuan yang memadai untuk mengembangkan peserta didiknya secara utuh. Untuk melaksanakan tugasnya 
secara baik, guru perlu menguasai berbagai hal termasuk kemampuan dalam pengelolaan kelas dan pembelajaran.

Pengelolaan kelas berbeda dengan pengelolaan pembelajaran. Pengelolaan kelas lebih menekankan upaya untuk menciptakan dan mempertahankan kondisi yang optimal saat terjadinya proses belajar. Pengelolaan kelas mencangkup pengaturan orang (peserta didik) dan fasilitas, penyiapan sarana dan alat peraga, pengaturan ruang belajar, mewujudkan situasi atau kondisi belajar dan mengajar berjalan dengan baik dan tujuan kurikuler dapat tercapai. Menurut (Gintings, 2008) pengelolaan kelas dapat diartikan sebagai upaya dan tindakan yang dilakukan oleh guru untuk menciptakan suasana belajar dan pembelajaran yang kondusif bagi tercapainya tujuan pembelajaran.

Sedangkan, pengelolaan pembelajaran lebih menekankan pada kegiatan perencanaan, pelaksanaan, evaluasi, dan tindak lanjut dalam suatu pembelajaran. Menurut (Sanjaya, 2009) pengelolaan pembelajaran adalah sebuah kegiatan untuk mengendalikan aktifitas pembelajaran untuk menncapai tujuan yang telah ditetapkan. Pengelolaan pembelajaran diawali dengan penentuan strategi dan perencanaan, proses dan diakhiri dengan penilaian.

Dalam pembelajaran yang terjadi di dalam ruang kelas, tentunya diharapkan mampu memaksimalkan dalam proses penyerapan materi yang di sampaikan oleh guru. Kondisi dan suasana kelas yang nyaman dan adanya metode pembelajaran yang baik serta tepat digunakan untuk menciptakan pembelajaran efektif.

Di dalam menempuh dan mewujudkan tujuan pembelajaran yang efektif maka perlu dilakukan sebuah cara agar proses pembelajaran yang diinginkan tercapai yaitu dengan belajar efektif. Untuk meningkatkan cara belajar yang efektif perlu adanya bimbingan dari guru.

Peran penting seorang pendidik dalam berlangsungnya proses pembelajaran sangat mempengaruhi hasil dari proses belajar. Guru seharusnya menguasai metode pembelajaran yang paling efektif dalam suatu kelas kemudian untuk diterapkan dan mengetahui kondisi-kondisi yang mempengaruhi peserta dalam pembelajaran. Adapun jenis-jenis kondisi belajar menurut Gagne (1977) sebagai berikut :

1. Kondisi internal (internal conditional) adalah kemampuan yang telah ada pada diri individu sebelum ia mempelajari sesuatu yang baru yang dihasilkan oleh seperangkat proses transformasi.

2. Kondisi ekstrernal (external conditional) adalah situasi perangsang diluar diri peserta didik. Kondisi yang diperlukan untuk belajar berbeda-beda untuk setiap kasus. Begitu pula dengan jenis kemampuan belajar yang berbeda akan membutuhkan kemampuan belajar yang berbeda dan kondisi eksternal yang berbeda pula.

Lingkungan disekitar peserta didik juga sangat berpengaruh bagi pribadi peserta didik. Hal ini seperti dikutip dari (Azwar, 2004) bahwa setelah kelahiran, pengaruh faktor lingkungan terhadap individu semakin penting dan besar. Faktor lingkungan memberikan pengaruh terhadap psikologi peserta didik. Lingkungan dapat berupa tempat dimana peserta didik tinggal, dan juga dimana peserta didik menempuh pendidikan. Lingkungan memberikan pembelajaran bagi peserta didik, 
Abidah Rohmatillah ${ }^{1}$, Aldila Septiani ${ }^{2}$, Efi Maysaroh ${ }^{3}$, Efri Roziaty ${ }^{4}$, Indah Purnamasari ${ }^{5}$, Meilinia Nurul Alfianti ${ }^{6}$, Kondisi Efektif Peserta Didik

yang mempengaruhi tingkah laku, kepribadian dan kompetensi. Perubahan ini disebabkan karena proses adaptasi dan proses pembelajaran yang terjadi.

Dari dua faktor dipaparkan diatas memberitahu kita bahwasannya keadaan peserta didik merupakan hal penting yang perlu diperhatikan oleh seorang guru, karena peserta didik merupakan objek utama sebagai komponen yang akan menerima pengetahuan baru dari seorang pendidik untuk mengembangkan bakat minat dan potensinya.

\section{METODE}

Dalam penelitian ini, kami menggunakan metode kualitatif dengan cara observasi langsung dan wawancara peserta didik. Tahap-tahap dalam persiapan, pelaksanaan, analisa data, sampai dengan penulisan laporan dilaksanakan di SMK Muhammadiyah 4 Surakarta, dengan waktu penelitian selama 2 minggu. Di mulai dari tanggal 28 Januari - 10 Februari 2020.

Subjek-subjek dalam penelitian ini adalah seluruh peserta didik kelas $X$ Farmasi di SMK Muhammadiyah 4 Surakarta. Objek dalam penelitian ini mencakup faktor-faktor yang mempengaruhi kondisi peserta didik dalam menyerap materi pembelajaran.Sumber data yang kami gunakan yaitu, data sarana dan prasarana yang mendukung pembelajaran di kelas dan kegiatan pembelajaran di SMK Muhammadiyah 4 Surakarta.

\section{HASIL DAN PEMBAHASAN}

\section{A. Hasil observasi kelas di SMK Muhammadiyah 4 Surakarta}

Pada bagian ini akan dipaparkan hasil observasi kelas dari mulai respon siswa dikelas sampai dengan cara mengajar guru di SMK Muhammadiyah 4 Surakarta

Kami memberikan penilaian dengan skala 1-5 untuk peran siswa, dan deskripsi proses pembelajaran untuk mengamati jalannya proses pembelajaran. Dengan rincian sebagai berikut:

1. Banyak peserta didik: 1 bila 0 sampai $>20 \%$; 2 bila $20 \%$ sampai $>40 \%$; 3 bila $40 \%$ sampai $>60 \%$ skor 4 bila $60 \%$ sampai $80 \%$; skor 5 bila $80 \%$ sampai $100 \%$ aktif.

2. Kualitas: 1 = sangat kurang; 2 = kurang; 3 = cukup; 4 = baik; 5 = baik sekali

3. Proses pembelajaran: Observer memberikan deskripsi sesuai dengan kondisi yang terjadi dalam proses pembelajaran.

\begin{tabular}{|c|c|c|c|}
\hline No & Aspek yang diamati & $\begin{array}{c}\text { Banyak } \\
\text { Peserta } \\
\text { didik } \\
\text { yang } \\
\text { Aktif }\end{array}$ & $\begin{array}{c}\text { Kualitas } \\
\text { Keaktifan }\end{array}$ \\
\hline A. & \multicolumn{3}{|c|}{ Pengetahuan dialami, dipelajari, dan ditemukan oleh peserta didik } \\
\hline 1. & Melakukan pengamatan atau penyelidikan & 4 & 5 \\
\hline 2. & $\begin{array}{l}\text { Membaca dengan aktif (misal dengan pulpen di } \\
\text { tangan untuk menggarisbawahi atau membuat } \\
\text { catatan kecil atau tanda-tanda tertentu pada } \\
\text { teks) }\end{array}$ & 5 & 5 \\
\hline
\end{tabular}




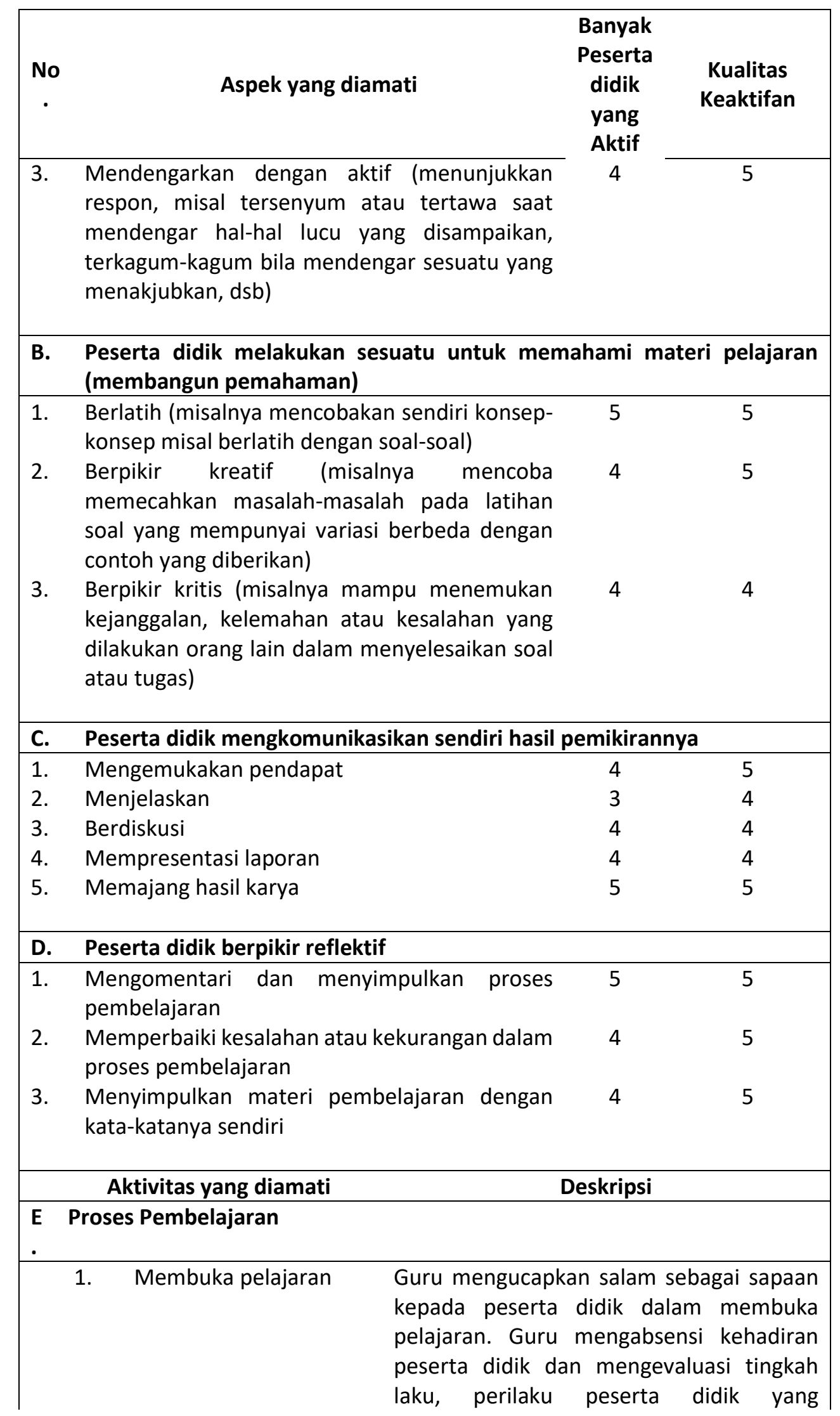


Abidah Rohmatillah ${ }^{1}$, Aldila Septiani ${ }^{2}$, Efi Maysaroh ${ }^{3}$, Efri Roziaty ${ }^{4}$, Indah Purnamasari ${ }^{5}$, Meilinia Nurul Alfianti ${ }^{6}$, Kondisi Efektif Peserta Didik

\begin{tabular}{|c|c|c|}
\hline $\begin{array}{c}\text { No } \\
\text {. }\end{array}$ & \multicolumn{2}{|c|}{$\begin{array}{cc} & \text { Peserta } \\
\text { Aspek yang diamati } & \text { didik } \\
& \text { yang } \\
& \text { Aktif }\end{array}$} \\
\hline & & $\begin{array}{l}\text { meyimpang, serta memberikan arahan } \\
\text { yang baik. Pembelajaran dimulai dengan } \\
\text { mengerjakan soal sebagai pengulangan } \\
\text { materi sebelumnya dan untuk mengetahui } \\
\text { tingkat kemampuan peserta didik dalam } \\
\text { memahami materi yang telah disampaikan }\end{array}$ \\
\hline 2. & Penyajian Materi & $\begin{array}{l}\text { Guru memberikan materi secara runtut dan } \\
\text { bertahap, dengan demikian memudahkan } \\
\text { siwa dalam menyerap materi dengan baik. } \\
\text { Kemudian guru memberikan latihan soal } \\
\text { sebagai alat ukur peserta didik bahwa } \\
\text { mereka mampu menangkap materi yang } \\
\text { disampaikan. }\end{array}$ \\
\hline 3. & Metode Pembelajaran & $\begin{array}{l}\text { Metode pembelajaran yang digunakan } \\
\text { adalah scientific. }\end{array}$ \\
\hline 4. & Penggunaan waktu & $\begin{array}{l}\text { Durasi pembelajaran yaitu jam Ke-3 ( } 08.50 \\
\text { - } 10.10 \text { WIB ). Dengan estimasi waktu } \\
\text { setiap } 1 \text { jam pelajaran selama } 40 \text { menit dan } \\
\text { guru menggunakan waktu tersebut dengan } \\
\text { baik }\end{array}$ \\
\hline 5. & Penggunaan bahasa & $\begin{array}{l}\text { Saat pembelajaran berlangsung, guru dan } \\
\text { peserta didik menggunakan bahasa } \\
\text { indonesia dan bahasa jawa. Walaupun } \\
\text { dominan penggunaan bahasanya adalah } \\
\text { bahasa jawa. Penggunaan bahasa jawa } \\
\text { dikarenakan bahasa jawa dinilai lebih } \\
\text { menimbulkan suasana yang akrab dan } \\
\text { hangat antara guru dan peserta didik, } \\
\text { pembelajaran juga terkesan serius tetapi } \\
\text { santai. Terciptalah suasana pembelajaran } \\
\text { yang menyenangkan. }\end{array}$ \\
\hline 6. & Gerak & $\begin{array}{l}\text { Ketika peserta didik mencoba mengerjakan } \\
\text { latihan soal, guru menghampiri peserta } \\
\text { didik dan membimbing dalam mengerjakan } \\
\text { soal pada peserta didik yang mengalami } \\
\text { kesulitan. }\end{array}$ \\
\hline
\end{tabular}




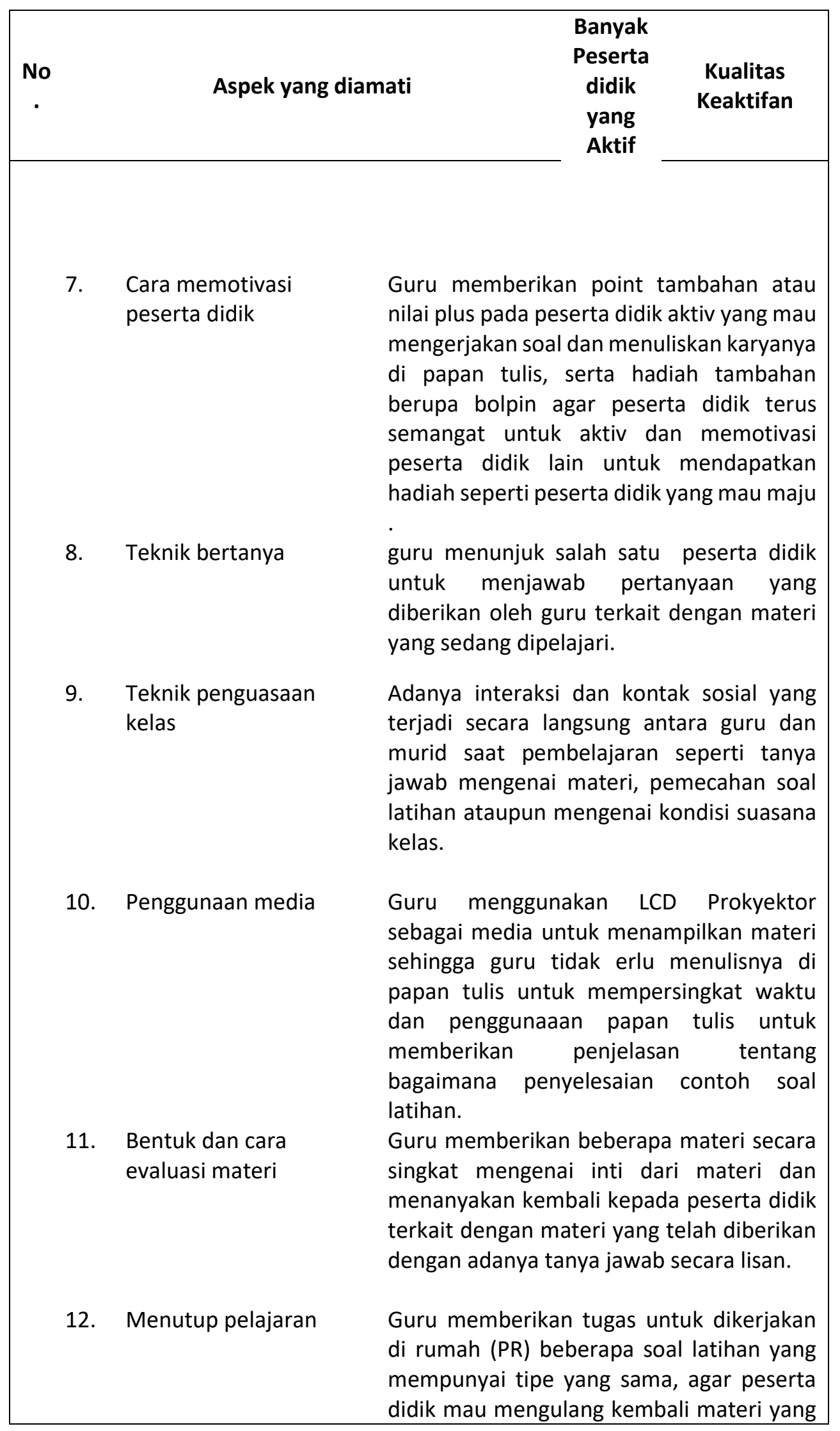


Abidah Rohmatillah ${ }^{1}$, Aldila Septiani ${ }^{2}$, Efi Maysaroh ${ }^{3}$, Efri Roziaty ${ }^{4}$, Indah Purnamasari ${ }^{5}$, Meilinia Nurul Alfianti ${ }^{6}$, Kondisi Efektif Peserta Didik

\begin{tabular}{|c|c|c|c|}
\hline $\begin{array}{c}\text { No } \\
\text {. }\end{array}$ & Aspek yang diamati & $\begin{array}{c}\text { Banyak } \\
\text { Peserta } \\
\text { didik } \\
\text { yang } \\
\text { Aktif }\end{array}$ & $\begin{array}{l}\text { Kualitas } \\
\text { Keaktifan }\end{array}$ \\
\hline \multicolumn{4}{|c|}{$\begin{array}{l}\text { telah mereka pelajari saat di rumah dan } \\
\text { mereka faham dengan betul materi yang di } \\
\text { sampaikan. Kemudian guru menutup kelas } \\
\text { dengan salam penutup. }\end{array}$} \\
\hline
\end{tabular}

\section{B. Pembahasan observasi kelas di SMK Muhammadiyah 4 Surakarta}

Hakikat pembelajaran efektif yang dimaksud adalah proses belajar mengajar yang bukan saja terfokus kepada hasil yang dicapai peserta didik, namun bagaimana proses pembelajaran yang efektif mampu memberikan pemahaman yang baik, kecerdasan, ketekunan, kesempatan, dan mutu serta dapat memberikan perubahan perilaku dan mengaplikasikannya dalam kehidupan mereka (Fakhrurozzi, 2018). Pembelajaran efektif juga akan melatih dan menanamkan sikap demokratis bagi peserta didik. Pembelajaran efektif juga dapat menciptakan suasana pembelajaran yang menyenangkan sehingga memberikan kreatifitas siswa untuk mampu belajar dengan potensi yang sudah mereka miliki yaitu dengan memberikan kebebasan dalam melaksanakan pembelajaran dengan cara belajarnya sendiri.

Dalam hasil observasi yang kami lakukan di kelas X Farmasi di SMK Muhammadiyah 4 surakarta ini, sudah memenuhi terciptanya pembelajaran yang efektif dengan hasil pembelajaran yang lebih optimal. (Kyriacou, 2009) menyatakan bahwa pembelajaran yang efektif dapat didefinisikan sebagai pembelajaran yang berhasil mencapai tujuan belajar peserta didik sebagaimana yang diharapkan oleh guru. Sedikitnya ada dua unsur pokok dala pembelajaran yang efektif, yaitu (1) guru harus memiliki suatu gagasan jelas tentang tujuan belajar yang diharapkan dan (2) pengalaman belajar yang direncanakan dan disampaikan dapat tercapai. Guru dapat memberikan pemahaman kepada peserta didik tidak hanya pada penyampaian materi pembelajaran melainkan juga memperhatikan sikap dan perilaku yang dilakukan peserta didik saat berada di lingkungan sekolah. Bagaimana ketika dalam proses belajar guru berusaha meningkatkan kepedulian mereka untuk saling membantu dalam proses belajar. Seperti contohnya ketika sedang berlangsungnya proses kegiatan belajar mengajar di kelas, guru meminta peserta didik untuk saling berdiskusi membentuk kelompok kecil dengan tujuan menyeselesaikan masalah yang dihadapi dan bersama-sama untuk bertukar pendapat agar mendapatkan solusi pemecahan masalah yang paling baik. Dari hal tersebut dapat kita simpulkan bahwasannya guru tidak hanya terfokus pada pengembangan kognitif peserta didik saja, melainkan juga memperhatikan sikap tindakan yang dilakukan peserta didik agar sesuai perilaku kemanusiaan yang beradap, sehingga mereka juga mendapatkan bekal untuk di terapkan di kehidupan sehari-hari agar menjadi manusia yang peduli dan bermartabat.

Menurut (Syah, 2013) secara global faktor-faktor yang mempengaruhi kondisi belajar siswa dapat dibedakan menjadi tiga macam, yaitu: 
1. Faktor internal (faktor dari dalam diri siswa), yakni keadaan jasmani dan rohani siswa. Yaitu: aspek fisiologis (jasmani, mata dan telinga) dan aspek psikiologis (intelegensi siswa, sikap siswa, bakat siswa, minat siswa dan motivasi siswa).

2. Faktor eksternal (faktor dari luar siswa), yakni kondisi lingkungan disekitar siswa. Yaitu: lingkungan sosial (keluarga, guru, masyarakat dan teman) dan lingkungan non-sosial (rumah, sekolah, peralatan dan alam).

3. Faktor pendekatan belajar, yakni jenis upaya siswa yang meliputi strategi dan metode yang digunakan siswa untuk melakukan kegiatan pembelajaran materi-materi pelajaran, yang terdiri dari pendekatan tinggi, pendekatan sedang dan pendekatan rendah.

Faktor internal yang dimiliki oleh siswa SMK Muhammadiyah 4 Surakarta yaitu memiliki motivasi belajar yang tinggi hal ini dibuktikan dengan sikap siswa di kelas yang ingin membaca dengan aktif dan membuat catatan kecil atau tanda-tanda tertentu pada teks. Siswa juga mempunyai keinginan untuk mendengar dengan aktif dan menunjukkan respon terhadap apa yang disampaikan oleh guru. Siswa juga dapat menyelesaikan latihan soal-soal yang diberikan oleh guru dengan berpikir kreatif dan berpikir kritis.

Faktor eksternal yang ada di sekolah ini meliputi, sarana dan prasarana yang sangat membantu dalam menciptakan kondisi belajar efektif. Seperti halnya komposisi ruang kelas, tentang jumlah peserta didik yang ada di kelas tersebut. Ini juga merupakan hal penting yang harus diperhatikan, karena ini akan mempengaruhi tingkat konsentrasi peserta didik. Selain itu jumlah peserta didik yang terlalu banyak juga akan membuat guru kesulitan untuk membagi perhatiannya kepada setiap peserta didik.

Jumlah peserta didik di SMK Muhammadiyah 4 Surakarta disetiap kelasnya terbilang cukup, karena SMK Muhammadiyah 4 Surakarta mempunyai murid yang tidak terlalu banyak, jadi guru di sekolah tersebut akan lebih mudah untuk memperhatikan dan memahami karakter setiap peserta didik disaat jam pelajaran ataupun disaat-saat lainnya.

Media Pembelajaran juga merupakan salah satu sarana dan prasarana sekolah. Menurut (Smaldino, 2011) Penggunaan media dalam pembelajaran merupakan sarana penunjang yang dapat meningkatkan efisiensi dan efektivitas keberhasilan pembelajaran. Media pembelajaran bisa menjadi sarana untuk meningkatkan daya tarik pelajaran agar pelajaran yang terlihat membosankan dapat menjadi menarik.

Dalam proses penjabaran materi, ada baiknya apabila peserta didik diberi kesempatan untuk berdiskusi dengan teman sebayanya, karena biasanya ada peserta didik yang mempunyai sifat akan bertambah tingkat kefahamannya apabila dijelaskan oleh teman sebayanya. Pada saat ini, guru juga diharapkan untuk berkeliling guna mengontrol dan memberi penjelasan ulang kepada peserta didik yang belum memahami materi tersebut.

Setelah proses pembelajaran di sekolah selesai, biasanya guru akan memberikan tugas terkait materi yang diajarkan hari ini. Menurut (Marunung, 2015) pekerjaan rumah merupakan tugas yang diberikan pada pelajar oleh guru sekolah untuk dikerjakan diluar sekolah. Alasan pemberian PR adalah untuk meningkatkan pemahaman siswa mengenai materi-materi yang diajarkan oleh guru. PR adalah alat untuk mempercepat langkah perolehan pengetahuan. PR dipercaya menjadi arti penting bagi kedisiplinan ingatan murid. Atau jika guru tidak 
Abidah Rohmatillah ${ }^{1}$, Aldila Septiani ${ }^{2}$, Efi Maysaroh ${ }^{3}$, Efri Roziaty ${ }^{4}$, Indah Purnamasari ${ }^{5}$, Meilinia Nurul Alfianti ${ }^{6}$, Kondisi Efektif Peserta Didik

ingin memberikan tugas, maka bisa diganti dengan membuat evaluasi materi dengan bentuk pertanyaan sederhana sebelum mengakhiri pelajaran.

Guru berperan penting dalam proses pembelajaran di sekolah. Adapun peran dan fungsi guru dalam meningkatkan mutu pendidikan Menurut (Usman, 2004) meliputi:

1. Guru sebagai demonstrator, berfungsi untuk mendemonstrasikan suatu materi pembelajaran, sehingga lebih mudah dimengerti dan dipahami oleh siswa. Oleh karena itu, guru harus mampu menguasai bahan atau materi pelajaran yang akan diajarkannya.

2. Guru sebagai pengelola kelas, berfungsi untuk mengendalikan dan mengorganisasikan siswa di dalam kelas agar lebih terarah kepada tujuan pembelajaran.

3. Guru sebagai mediator dan fasilitator, berfungsi untuk memperagakan suatu media atau alat pembelajaran yang mendukung materi sehingga siswa lebih merasa jelas.

4. Guru sebagai evaluator, berfungsi untuk mengevaluasi hasil belajar siswa.

Guru di SMK Muhammadiyah 4 Surakarta sudah menerapkan peran dan fungsi guru dengan baik, hal ini ditunjukkan dalam hasil observasi kami di kelas X Farmasi.

Faktor pendekatan belajar yang dilakukan siswa dalam proses pembelajaran meliputi kegiatan mengemukakan pendapat dengan baik, berdiskusi dengan tutor sebaya, mempresentasikan hasil diskusi di depan siswa yang lain.

Pembelajaran dengan tutor sebaya mempunyai manfaat untuk peserta didik. Menurut (Djamarah, 2006) manfaat tersebut antara lain: 1) ada peningkatan hasil bagi siswa yang enggan bertanya atau takut pada gurunya, sehingga dengan tutorial ini diharapkan siswa dapat leluasa bertanya pada temannya sendiri, 2) mempererat huungan antara sesama teman sehingga rasa sosial semakin kuat, 3) bagi tutor akan memperkuat konsep yang telah diterima, karena dengan mengajarkan kembali pada siswa yang lain maka ia akan belajar, 4) para tutor memperoleh kesempatan untuk melatih diri memegang tanggung jawab dalam mengemban suatu tugas dan melatih kesabaran.

\section{SIMPULAN}

Proses pembelajaran di sekolah adalah salah satu kegiatan transfer ilmu pendidikan, bagaimana seorang peserta didik mendapatkan ilmu pengetahuan di bangku sekolah. Dan sekolah sebagai tempat utama berlangsungnya proses tersebut.

Dari hasil pengamatan kami, baik guru maupun siswa telah sama-sama menerapkan kondisi pembalajaran yang efektif. Peserta didik dengan aktif menciptakan suasana belajar yang nyaman menurut dirinya, serta guru yang mendukung siswa untuk menyampaikan materi sesuai dengan kurikulum yang berlaku. Hal ini menjadi suatu kesinambungan yang sangat efisien bagi proses pembelajaran.

\section{DAFTAR PUSTAKA}

Azwar, S. (2004). Pengantar Psikologi Intelegensi. Yogyakarta: Pustaka Pelajar.

Djamarah, S. (2006). Strategi Belajar Mengajar. Jakarta: PT Rineka Cipta. 
Fakhrurozzi. (2018). Hakikat Pembelajaran yang Efektif. Jurnal At Tafkir, 85-99.

Gintings, M. A. (2008). Esensi Praktis Belajar \& Pembelajaran. Bandung: Humaniora.

Kyriacou, C. (2009). Effective Teaching in Schools : Theory and Practice. Third Edition. Delta Place, Cheltenham, UK: Nelson Thornes Ltd.

Marunung, S. H. (2015). Analisis Faktor-Faktor yang Mempengaruhi Keefektifan Belajar Matematika di MTs Negeri Rantau Prapat. Jurnal Edu Tech Vol 1 No 1, 1-16.

Sanjaya, W. (2009). Kurikulum dan Pembelajaran (teori dan prakti pengembangan KTSP). Jakarta: Kencana Prenada Media Grup.

Smaldino. (2011). Instructional Technology \& Media for Learning Teknologi Pembelajaran dan Media untuk Belajar. Jakarta: Kencana.

Syah, M. (2013). Psikologi Pembelajaran dan Pengajaran. Bandung: PT. Remaja Rosdakarya.

Usman. (2004). Menjadi Guru Profesional. Bandung: Angkasa. 